\title{
In the Name of Human Capital
}

The International Recruitment of Physicians in Germany and Spain

Claudia Finotelli

CMS 2 (4): 493-517

DOI: 10.5117/CMS2014.4.FINO

\begin{abstract}
The international migration of physicians is considered an effective response to ageing societies. However, the international recruitment of physicians may be challenged by the protectionist rationale of the medical profession in many countries. How is the potential contradiction between open recruitment policies and exclusive professional regulations managed in Europe? What is the role played by foreign credential recognition or language knowledge in the recruitment process? Are there differences among countries? These questions are analysed by comparing Germany and Spain, which possess not only two divergent migration regimes but also two completely different health care systems. The main goal of the article is to explore how the capacity of national health care sectors to attract and integrate foreign physicians may affect Europe's quest for highly skilled health professionals in the long term.
\end{abstract}

Keywords: Germany, Spain, labour migration, highly skilled migration, health care system, physicians, foreign credential recognition, human capital

\section{Introduction}

Immigration is often suggested as the best possible way to meet the growing demand for highly skilled professionals in ageing societies. In view of this, the formerly restrictive immigration policies prevailing in European immigration countries have given way to increasing efforts to respond to economic and demographic needs through active labour migration policies. However, as with many types of migration processes, the interna- 
tional migration of highly skilled workers is a multifaceted process involving several actors interacting at the state level. Employers' strategies, labour market structures, language skills and foreign credential recognition processes must be taken into account when assessing a nation state's capacity to attract (and integrate) highly skilled foreign labour (Jinks et al., 2000; Peixoto, 2001; Bommes et al., 2004; Hoesch, 2012).

This article analyses to which extent internal barriers to workers' selection such as foreign credential recognition, assessment of professional qualifications or language knowledge may challenge increasing openness toward the recruitment of highly skilled workers in the European Union. To do this, the analysis focuses on the recruitment of foreign physicians in Germany and in Spain. The reasons for this choice are twofold. First, the medical profession is one of the professions with the most restrictive access in comparative perspective (Freidson, 1970; Tousjin, 2009). In addition, health care markets have "unique characteristics" that "imply great complexity in developed economies involving government intervention, licensure, regulation, and (quasi-) union activity" (Grignon et al., 2012:3). Second, the choice of Germany and Spain as suitable comparative cases is based on their divergent migration histories (an old versus a new immigration country) and the different structure of their health care systems (a social security financed system in Germany versus a tax-financed system in Spain).

The first objective of the article is to assess to what extent the international demand for high-skilled health professionals can be fulfilled in a highly regulated sector, such as health care, and which factors may hamper recruitment procedures and labour market insertion. The second objective is to shed light on the reasons for divergence in recruitment policies in the European Union, where 27 different health care systems coexist in different socio-economic contexts with different professional regulations. The analysis focuses on structural conditions such as foreign credential recognition, language requirements or salary standards without disregarding the influence of other contextual variables such as a country's economic situation, which is considered particularly relevant to the Spanish case.

The empirical material collected for the analysis consists of a series of expert interviews conducted with professional and institutional representatives in Spain and in Germany between the spring and summer of 2013 as part of the project 'Labour Migration Governance in Contemporary Europe' (LabMigGOv) (Finotelli, 2014). The interviewees include in particular representatives of organisations indirectly involved in the design and/or implementation of labour migration policies such as regulation bodies in Germany and trade unions in Spain. The interviews are comple- 
mented by administrative memos, which have been particularly useful for the German case.

The first section provides a brief overview of the existing debates on foreign recruitment of physicians. The second and third sections of the article analyse the recent evolution in the health care regimes of Germany and Spain respectively, focusing on those factors that contributed to "opening" the medical profession over the past few years. In the fourth and fifth sections, the analysis considers which types of inclusion barriers persist in Germany and Spain despite more open recruitment regimes. The final discussion explores the ways in which the recruitment and integration of foreign physicians into national health care systems can affect Europe's quest for human capital.

\section{The International Recruitment of Foreign Physicians: A Brief Overview of Policies and Challenges}

It is widely acknowledged that ageing populations, new technologies and the unattractiveness of health care professions to young doctors represent major challenges for European health care. The international recruitment of physicians is seen not only as the most effective way to respond to demographic challenges but also as an opportunity to improve healthcare systems and enhance their competitiveness (Forcier et al., 2004; Buchan, 2006). As declared by the EU Commission in its "Green Paper on the European Workforce for Health", "to respond adequately to these challenges requires health systems to have efficient and effective work forces of the highest quality as health services are very labour intensive" (EU Commission, 2008:1).

In accordance with this goal, the recruitment and integration chances of foreign physicians have been improved in the European Union within the regulation framework approved to foster the intra- and extra-EU mobility of academics. Since 1975, EU members almost automatically recognise academic degrees obtained at any officially recognised university in the European Union. The EU directive 2005/36/EG of 7 September 2005 regulates the recognition of specialty training after a degree in medicine, allowing automatic recognition of specialty training carried out in an EU member state and so lifting a further labour market barrier to the intraEuropean circulation of EU physicians and other professional practitioners. $^{1}$

Recruitment opportunities for non-EU physicians and other highly 
skilled professionals have been also recently improved by approving the so-called 'Blue Card' directive, n. 2009/50/EC, which allows recruitment of highly skilled workers (including physicians) from non-EU countries and defines common employment conditions across Europe. Undoubtedly, the directive represents a milestone of the new European migration regime after 25 years of restrictive orthodoxy. The directive's principal aim is to increase EU attractiveness to highly skilled non-EU migrants to enhance Europe's "international strength" (EU Commission, 2007: 1) and consolidate Europe's transformation into a "competition state" (Lavenex, 2006). Notwithstanding the remarkable progress achieved by EU regulation in the last decade, the mechanisms that promote the international mobility of foreign physicians remain an underresearched topic. As Wismar et al., (2011) highlight, little is known about the dimensions of health professional mobility, its driving forces and the corresponding country responses. In fact, much scholarly attention has been devoted to the 'brain drain' effects of physician recruitment on the immigrants' countries of origin (Docquier and Bhargava 2006).

In contrast, knowledge is more limited on policies and obstacles related to physician recruitment and labour market inclusion in host countries (Dussault et al, 2010; Glinos, 2014). In this respect, Den Adel et al, (2004) have been among the first to argue that international recruitment in the health care sector is deeply embedded in the structural conditions of destination countries. Different sources of financing and degrees of corporatism can, for instance, explain why some countries are more reluctant than others in recruiting non EU-physicians (Hoesch, 2012). Other scholarly works have focused on the relevance of the recognition of foreign credentials, showing that Member States traditionally have fewer possibilities to create employment barriers in the non-regulated ICT sector (Kolb et al., 2004) while the recognition of foreign credentials of non-EU foreigners is very relevant to practice in regulated professions (Bommes et al., 2004; Ribeiro, 2008a). In most countries, engineers, lawyers and physicians must indeed pass strict foreign credential assessments (Sumpton, 2013; Dixon, 2013). Despite this, physicians seem to have a special status among them since medicine, as Eliot Freidson noted, "even in circumstances where it is not fully free of state control, it is at the very least formally free to control the content if not the terms of its own work" (Freidson, 1970: 18). The medical community has developed several methods of regulation, such as ethical codes or credential recognition procedures, to keep a certain level of trust in the medical profession and protect recognised community members from the "infiltration" of unqualified candidates. 
Scholars have highlighted that the high degree of protectionism affecting the health care sector may have a negative impact on the labour market integration of foreign physicians, who may be considered "system outsiders" by national medical communities. A noteworthy example in this respect are Canada and Australia, where the strict norms of licensing bodies in health professions have long constituted a barrier to the employment of physicians, despite the openness of their internationally praised human capital models (Iredale, 2001; McGrath, 2004; Boyd and Schellenberg, 2007). Besides foreign credential recognition, the knowledge of the host country language is considered particularly relevant for performance in the health care sector while in the high-tech or engineering sector, interaction is often possible in English. However, the question of language proficiency has been often analysed as a barrier to access to health care services (Kale and Raza Syed, 2010) but seldom as a barrier to recruitment and successful labour market inclusion of foreign physicians.

Overall, this brief overview of the existing debates on foreign recruitment in the health care sectors reveals that there is an increasing need to deepen knowledge on the potential contradiction between inclusive recruitment policies for third-country nationals in the European Union with exclusionary practices related to credential recognition or language requirements. A comparison between the Spanish and the German recruitment models is expected to provide some insight into this particular policy field.

\section{International Recruitment in the German Health Care Sector}

Germany has a statutory social-security-based health care system, where state health insurance (gesetzliche Krankenversicherung) is financed by social security contributions to different insurance companies, which covered two-thirds of health care spending in 2011 while the remaining onethird is mainly privately financed (Paris et al, 2010). Organisationally, the German health care sector is characterised by a high degree of corporatism and self-administration, in which representatives of social insurance and doctors negotiate contributions and performance at the margins of the national state budget. The high level of autonomy of professional corporations and the independence from state budget concerns have transformed this sector into an independent sub-system in which physicians' corporations are particularly well-organised (Hoesch, 2012). Physicians can work 
either in a hospital or in independent practices, for which the number, type and distribution are stipulated by the regional organisations of independent physicians (Kassenärztliche Vereiningungen). Individual physicians charge social insurance for their services and thus, many German medical practices function as small enterprises mainly interested in financial benefit (Hoesch, 2012).

Access to the medical profession is regulated by each Land, the German federal unit. To work in Germany, physicians need a full licence to practice (Approbation) issued by the state health authorities (Oberste Landesgesundheitsbehörde) of the respective federal unit. The full licence to practice is conditio sine qua non to practice as a generic doctor, start medical training and to practice then as a specialist. Until 2012, however, $\S 3$ of the German regulation of the medical profession (Bundesärzteordnung) stated that only German and EU citizens could apply for the full licence to practice. In addition, Germans or EU citizens that had studied in a non-EU country or ethnic Germans had to pass a state of knowledge exam (Kenntnisstandprüfung) to get a full licence (Englmann and Müller, 2007). Issuing the full licence to non-EU citizens was only possible under a restricted number of exceptional circumstances, whose interpretation was highly discretionary and almost always ended with the application's withdrawal (Schiller, 2010). The nationality criterion was considered a matter of "national interest" because physicians practicing in Germany were expected to understand the way of life and the needs of their patients and to know about customary therapies as well as to possess knowledge about the juridical norms regulating the practice of the medical profession (Espeler, 2000). However, restrictions also applied to non-EU citizens that had been studying at a German university and to third-country nationals that had undergone specialty training in Germany, all of whom could be assumed to be familiar with German medical practice but did not have the right to apply for a full licence (Yamamura, 2009). The power of medical corporations, the independence of the German health care system from politics and the long-lasting German non-immigration dogma all contributed to maintaining the nationality requirement for many decades. In this period, non-EU physicians could practice only on the basis of a temporary licence to practice (Berufserlaubnis) that was geographically and temporally limited. It was generally issued for a maximum of seven years and could only be renewed under a limited number of exceptional circumstances (Yamamura, 2009). Temporary licences were limited to the activities of an assistant doctor and did not allow foreign physicians to open their own clinics on German territory. In addition, the issuance of a temporary licence was 
not dependent upon a comprehensive state of knowledge examination but only on the individual assessment of certified information about medical training abroad.

Overall, the temporary licence helped to solve the problem of the demand for physicians in hospitals and some rural areas, accomplishing at the same time an immigration policy based on temporal and geographical limitations to avoid immigrants' permanent settlement. Clearly, the international migration of physicians was seen as a temporary phenomenon to fill gaps in hospitals, but the same were excluded from the possibility of settling in the country and participating in the medical business by opening their own practices (Hoesch, 2012).

The strict regulation of the medical profession contrasted with the growing debate on (and concern for) the shortage of physicians in Germany. In 2001, the Federal Chamber of Physicians (Bundesärztekammer) declared that the increasing number of retiring doctors, the high emigration figures for German specialists (by 2010, 17,000 doctors had already left Germany, mainly to work in Switzerland or the USA) and the growing feminisation of the medical profession were enhancing the demand for certain specialties (especially general practitioners) in Eastern German Länder and rural areas (Kopetsch, 2010; Blüm and Löffert, 2010). The contradiction between an oversupply in metropolitan areas and an undersupply in rural areas explains why German scholars were increasingly worried about shortages, despite a ratio of 3.84 doctors to 1,000 inhabitants in 2011, one of the highest in Europe (OECD, 2011). No consideration, however, was devoted to the question of international recruitment. Rather, the Federal Chamber focused on the search for functional alternatives, such as increasing the attractiveness of a medical career to young students, improving working conditions for doctors in German hospitals or enhancing intra-EU circulation.

Only since 2010 have the restrictions on the entry of foreign physicians started to relax. The idea that the health care sector should be open to nonEU physicians was supported by the new German immigration Zeitgeist. In 2012, the German government ratified the 'Blue Card' directive, allowing highly skilled professionals to enter the country if minimum salary conditions were fulfilled. 'Blue Card' applicants in MINT professions (Mathematics, Informatics, Natural Sciences and Technology) and physicians were exempted from the labour market check. Moreover, for MINT professionals and physicians, Germany lowered the minimum salary requirements to 36,192 euros (instead of the 46,400 euros for other highly skilled occupations). Such a salary, which is far below the amount that many 
German (but also EU) physicians would accept to work in Germany, allows the hiring of young doctors in their first year of specialty, which would not have been possible under the previous salary requirements. ${ }^{2}$ Further, the new law for the recognition of foreign credentials (Berufsqualifikationenanerkennungsgesetz, $B Q F G$ ) established the right of every non-EU citizen to apply for foreign qualifications in Germany. This goal was achieved by transposing the recognition rules for EU citizens, as regulated by directive no. 36/2005/EU, onto the new German recognition law, extending their validity to third-country nationals. Since then, foreign credential recognition in Germany has no longer depended on the applicant's nationality but on the country in which the applicant has obtained his or her medical degree. Finally, German legislation declares that doctors must possess "necessary knowledge of the German language" but does not provide information on what level of language is required or how such knowledge is to be assessed. The German Länder have informally agreed on the intermediate level $\mathrm{B}_{2}$ as a minimum level for foreign physicians. Then, it is up to the recognition office to decide whether a simple language certificate suffices or if an additional language test is required.

The new provisions were particularly significant for foreign physicians because, for the first time, doctors from non-EU countries had the right to apply for foreign credential recognition and therefore obtain a full licence to practice in Germany. Clearly, as the president of the Federal Chamber noted, the new recognition law could not coexist with the old §3 of the Federal Medical Regulation, where nationality (and not the country where the degree was obtained) was the main criterion to apply for a full license in Germany (Bundesärztekammer, 2011a).

The approval of the new recognition law, however, should not be considered a surprise but rather the outcome of the interplay between deep changes affecting the German migration and health care sectors. First, a widespread consensus on the need for highly skilled migrants had grown in Germany (Laubentahl, 2012; Kolb, 2014). Second, as Döhler and Manow (1995: 151) highlighted, federal intervention had increasingly put the German health care sector "under stress" since the health system reform of 1992 (see also Hoesch, 2009). Third, European integration had contributed to the development of a "dual" recognition system with respect to medical careers equalising the medical degrees and medical training of EU citizens to German degrees if obtained in an EU country. Moreover, since 2007, medical degrees obtained in Australia, Israel, Japan, Canada and New Zealand were considered objectively equivalent (objektive Gleichwertigkeit) to German degrees. In view of the aforementioned changes, it is 
therefore no surprise that applications for credential recognition by nonEU physicians were accepted as the inevitable consequence of the evolution towards a more open immigration approach, from which non-EU physicians could hardly be excluded.

\section{The Internationalisation of the Spanish Health Care Sector}

The Spanish National Health System, created in 1986, is based on universal insurance and is financed through tax allocations and assignments from general state budgets. Nonetheless, Spanish citizens are allowed to obtain private insurance. Tax funding and a very low degree of professional corporatism make the health care system highly dependent on state politics (De Miguel, 1982). Although health competencies have almost completely been transferred to the Autonomous Communities (the Spanish federal units), the organisation and development of medical careers lie within the power of the central government and, in particular, the Ministry of Health. In fact, the central government in Spain still plays a major role in designing access to medical training and in regulating foreign credential recognition, whereas the employment of health professionals after specialty training is a function of the Autonomous Communities. The central administration organises the medical profession and decides who may practice. This control inevitably weakens physicians' control over the profession and makes recruitment more dependent on general immigration policy concerns than in Germany (Rodriguez, 1981).

Before being employed as physicians in the Spanish health care system, young graduates must complete a five-year medical training period at a Spanish hospital. Physicians' access to medical training to become an "internal resident doctor" (medico interno residente, MIR) depends on their rank after taking a state examination (the so-called MIR exam). Training slots are assigned by the Ministry of Health to each university hospital based on requests presented by the Autonomous Communities. The state examination results determine the choice of specialty: the higher the score on the state examination, the greater the chances the candidate will be able to pursue the desired specialty in the desired hospital. In contrast to Germany, third-country nationals have been allowed to apply for their degree recognition to take the state exam. However, the access of non-EU foreigners to medical training has been formally limited by a "cap for 
foreigners" (cupo de extranjeros) on the total slots available, which could not exceed 10 per cent of all available training slots.

The nationality criterion clearly had a limiting function that started to be questioned only at the beginning of the new century because of the growing "feeling" that Spain needed more doctors (Confederación Española de Sindicatos Médicos (CESM), medical trade union, personal communication, October 17, 2011). Such "feeling" was embedded in a deep mismatch. On the one hand, Spain has a ratio of 4.1 practising physicians for 1,000 inhabitants, one of the highest in the European Union (OECD, 2011). On the other hand, physicians in Spain tended to concentrate in Madrid or in other important urban centres, while hospitals in the interior regions and on the islands remained understaffed because they were unattractively located (Amaya Pombo and García Pérez, 2005). Such disparity was exacerbated by autonomous governments profiting from the "spending euphoria" during the economic boom by building new hospitals in rather isolated regions without increasing human resources. Moreover, a sizeable number of Spanish physicians had left Spain to practice or do their medical training in other countries such as Portugal (Ribeiro, 2008b). Family and Community Medicine (FCM) was particularly undersupplied, because it was considered less prestigious than other specialties; it also provided fewer chances for professional development (González LópezValcárcel et al., 2011). ${ }^{3}$

As a result, several training slots in unattractive specialties, often located in isolated regions of the Spanish interior, remained vacant. Consequently, the Spanish Ministry of Health in 2007 modified the regulation of the medical training exam, eliminating the cupo for non-EU citizens after increasing the number of training slots from 5,200 in 2003 to 6,388 in 2007. The only requirement was to have a valid residence or study permit and foreign credential recognition being processed at the time of the exam. Moreover, non-Spanish speaking applicants were requested to certify sufficient knowledge of the Spanish language. If successful, the applicant was required to legalise his or her position according to the requirements of each Autonomous Community. The new regulation triggered substantial growth in foreign credential recognitions processed by the Ministry of Education. In 2010, 34 per cent of the applicants for available training slots were foreigners, most of them from non-EU countries.

Apart from the recruitment of resident doctors, it was possible to recruit non-EU specialists abroad because certain types of medical specialties had been included in the Catalogue-of-Hard-to-Find-Occupations. ${ }^{4}$ In such cases, labour market insertion also depended on specialty recognition. 
The recognition procedure for specialists, possible only for applicants with a recognised academic degree in medicine, was centrally regulated and carried out by an evaluation commission of specialists whose members are chosen by the Spanish Ministry of Health (R.D. no. 459/2010). Several observers agree that specialty recognition was more time-consuming than degree recognition; the general tendency is to reject the application of nonEU citizens if their specialisation is not equivalent to European standards. Currently, no statistics about specialty recognition are available. However, the Ministry of Health seems to have a large application backlog, which confirms that specialty recognition is a particularly burdensome channel to practicing medicine in Spain (Ramirez, 2013; Consejo General de Colegios Oficiales de Médicos (CGCOM), professional corporation, personal communication, Madrid, July 24, 2013).

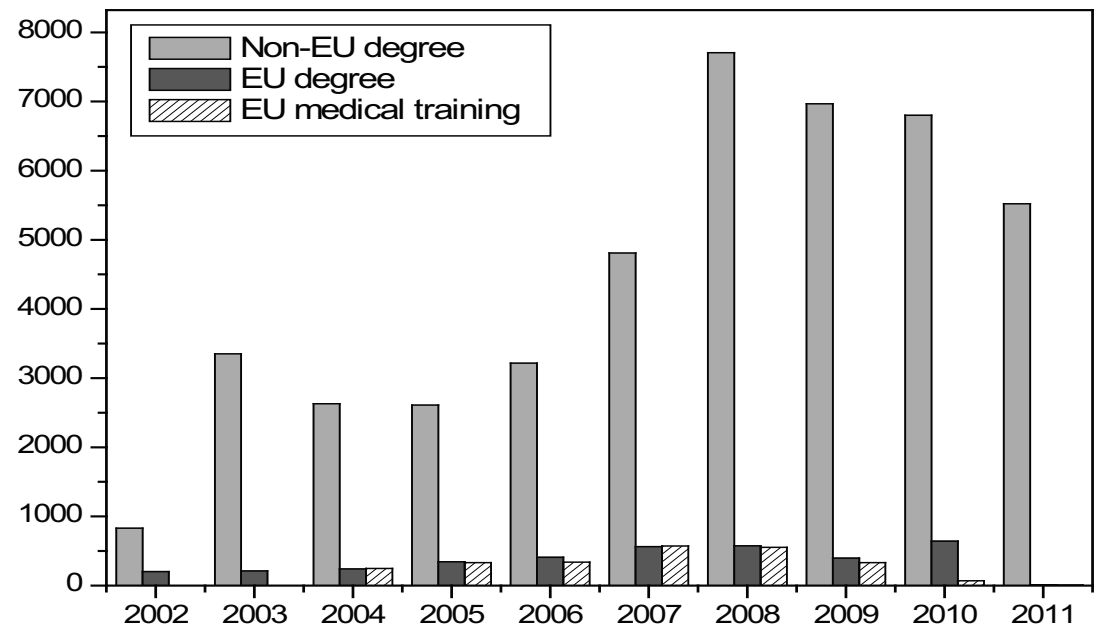

Figure 1: Recognition of foreign medical degrees in Spain (excluding specialty recognition)

Overall, the opening process experienced by the Spanish health care sector is remarkable considering that the Spanish immigration model has been mainly targeted at attracting low-skilled workers. As with other types of highly skilled migration, Spanish policy-makers, aware of the widespread criticism about the recruitment of foreign physicians, preferred to avoid a public debate on the issue. Scholars had warned of the consequences of increasing the number of training slots without carrying out structural reforms, warning that it would be difficult to absorb the larger number of medical school graduates in the long term (Amaya Pombo and Garcia 
Perez, 2005). Trade unions were also against the new recruitment scheme. According to a representative of the Spanish physician trade unions, the solution for structural problems did not rest in the recruitment of professionals from non-EU countries (Confederación Española de Sindícatos Médicos (CESM), medical trade union, personal communication, Madrid, October 17, 2011). Similarly, the representative of the Spanish "General Workers' Union" (Unión General de Trabajadores, UGT) expressed serious concerns about the recruitment of non-EU physicians, arguing that they would not be employed in hospitals or ambulatories but rather in private centres for the care of elderly or dependent people "as a way to reduce costs" (Unión General de Trabajadores, trade union, personal communication, Madrid, May 27, 2011). Finally, it was argued that the Spanish health care system could not solely rely on the recruitment and employment of resident doctors often endorsed with duties far beyond their actual competence and a gross salary, which ranged from 900 to 1,500 euros, depending on the Autonomous Community (Consejo General de Colegios Oficales de Médicos, professional corporation, telephone interview, July 24, 2013). However, as with many other issues related to labour migration in Spain, any criticism was overshadowed by euphoria about the economic boom, which was reflected by an annual GDP growth rate of 4 per cent in 2006 (http://data.worldbank.org). Only the economic crisis brought to light the contradictions and shortcomings of international labour recruitment in the Spanish health care sector and, with it, the barriers to the recruitment and insertion of foreign workers.

\section{International Recruitment of Health Professionals in the Crisis}

During the economic boom, the Spanish health care sector developed into an "employment bubble" without taking into account the long-term consequences of training an increasing number of physicians. In this context, the decision to attract resident doctors from third countries can be seen more as a "reactive" measure, which was used to correct the symptoms of labour market dysfunction without addressing the causes. Little consideration was given to the possibilities of long-term employment after medical training. Permanent employment in the Spanish public health sector, as with all permanent positions in the Spanish civil service, is usually limited to Spanish nationals and EU citizens. Therefore, for non-EU physicians, employment in the public sector was often limited to temporary employ- 
ment as long as the medical profession was included in the Catalogue of Hard-to-Find Occupations; the only possibility of getting a permanent contract was in the private sector. In this respect, the position of non-EU doctors in Spain was not very different from that of many non-EU doctors in Germany before 2012, who could be employed only with a temporary licence to practice.

The situation worsened with the economic crisis in 2009, when GDP growth rate plummeted to -3.8 per cent and unemployment increased to 16.8 per cent (www.ine.es, www.worldbank.org). Budgetary restrictions reduced the possibilities of employment in Spanish hospitals for specialists, while the fear of unemployment made unattractive specialties, such as Family Medicine, more attractive to young natives (Harris et al, 2013). Consequently, the Spanish government decided to restrict again the access of non-EU physicians to the Spanish health care sector by eliminating physicians from the Catalogue and limiting the access of non-EU foreigners to medical training. Not surprisingly, the decision had a reactive character, as an interviewee of the Spanish doctors' trade union commented: "Now that the ministry has decided to return to the previous situation, the feeling is that there are too many doctors in Spain" (Confederación Española de Sindicatos Médicos (CESM), medical trade union, personal communication, Madrid October 17, 2011). However, the cap on third-country nationals has been re-introduced and it has been considerably reduced in comparison with the past. According to the current regulation, only four per cent of non-EU citizens who pass the state examination are allowed to choose a medical training slot in Spain. This means that non-EU citizens may be denied access to medical training despite having a recognised degree and achieving a good ranking position on the state examination. The cap also applies to non-EU citizens who obtained their medical degree at a Spanish university, a decision that has been sharply criticised by professional bodies, such as the CGCOM, and whose exclusionary character is similar to the German provisions before the recent legislation changes. The CGCOM officially complained about this restrictive rule, to which the Ministry of Health reacted, stating that coming to Spain for medical training is an immigration matter and therefore depends on the applicant's nationality, not on where the degree was obtained (Consejo General de Colegios Oficiales de Médicos, professional corporation, telephone interview, September 13, 2013).

After the recent reforms, non-EU physicians have very few possibilities of working in Spain. In fact, they not only have limited access to medical training but also few chances to work in the public and private sectors. 
First, the employment of non-EU physicians in private and public institutions is now subject to a foregoing labour market check. Second, the few permanent positions offered in the public sector are still restricted to Spanish and EU citizens. The nationality criterion inevitably draws attention to the role of naturalisation and the discriminatory character this requirement may have on the general recruitment of non-EU physicians in Spain. According to current citizenship law, Spanish nationality can be obtained after ten years of legal residence. However, citizens of South American countries, Portugal, Equatorial Guinea and the Philippines can apply for Spanish citizenship after two years of legal residence. The asymmetrical treatment in favour of Latin Americans may turn naturalisation into a strategy to access the medical profession despite unfavourable labour immigration rules. Positive discrimination in favour of Latin Americans may also be strengthened by recent language requirements. Since 2011, physicians from a country whose official language is not Spanish must demonstrate sufficient knowledge of Spanish (Level C1 or C2) according to either the classification of the Cervantes Institute or the official language institute in the applicant's country of origin. This novelty has been explained by the need to improve communication skills between doctors and patients and the necessity to adapt to requirements set by the EU directive on the recognition of professional qualifications. With this new rule, however, language requirements may turn into a further instrument of positive discrimination favouring the recruitment of naturalised Latin Americans to the detriment of other national groups, including, paradoxically, EU citizens.

As recent developments show, new nationality-based restrictions to select residents in Spain were introduced despite the new European Zeitgeist in favour of highly skilled migration; this shows how Spanish health care reform (and its selection mechanisms) was deeply embedded in national contingencies and structures. In this regard, Spain experienced a reverse trend with respect to Germany: Spain became more restrictive by strengthening nationality requirements for medical training, while Germany lifted its nationality-based entry barriers for physicians and other highly skilled foreign workers. Nevertheless, enthusiasm about the ground-breaking character of any new recruitment opportunities should not prevent a serious reflection on hidden shortcomings and contradictions to assess to what extent new forms of control a posteriori may emerge in the future German immigration model. 


\section{Germany: The New Promised Land for Foreign Physicians?}

Germany's new immigration regime represents one of the most recent significant novelties in the European migration panorama. As a recent OECD report observes, Germany now belongs to "the OECD countries with the fewest restrictions on labour migration for highly skilled occupations" (OECD, 2013: 15). Such a shift is particularly relevant for non-EU physicians, in a sector where the high degree of corporatism was considered a major obstacle to the opening of the health care sector to foreigners (Hoesch, 2012). German physicians' organisations viewed with scepticism the recruitment of non-EU physicians. Still, in 2008, the Marburger Bund, the German non-governmental organisation of hospital physicians, argued against the recruitment of non-EU doctors, "since this professional group is urgently needed in their country of origin to take care of the native population" (Marburger Bund 2008: 4-5). Few, however, would have imagined that three years later, the German law would allow foreign recruitment of nonEU doctors without the need for a previous labour market check and, at the same time, lift the nationality requirement for non-EU doctors to apply for a full licence.

However, this shift did not prevent the Federal Chamber from demanding more restrictive recognition procedures for applicants from non-EU countries. In particular, the Chamber suggested that non-EU physicians must pass the complete state of knowledge examination in the case of major differences between German medical training and the applicant's training. In a subsequent letter, the Chamber reiterated its request, stating that stricter recognition requirements for degrees obtained in non-EU countries would be useful to preserve the quality and level of the German education system (Bundesärztekammer, 2011b). Clearly, the Federal Chamber requested the adoption of different evaluation criteria depending on the country where the degree was issued to keep control over the inclusion of outsiders.

The Chamber prevailed in its claim. Degrees obtained in an EU country are automatically recognised if the applicant provides an "education certificate" (Ausbildungsnachweis) issued by the country where he or she obtained the degree. In the case of degrees obtained before 20 December 1976 and only if deficits are observed, applicants with an EU degree have to pass a partial examination. By contrast, all non-EU citizens must pass a complete examination if deficits are detected. ${ }^{5}$ In this way, state chambers and state governments keep control a posteriori of the recognition of foreign 
credentials of non-EU physicians. Even though the number of foreign doctors has been increasing since 2010 (figure 2), very few data have been provided about recognition procedures to date.

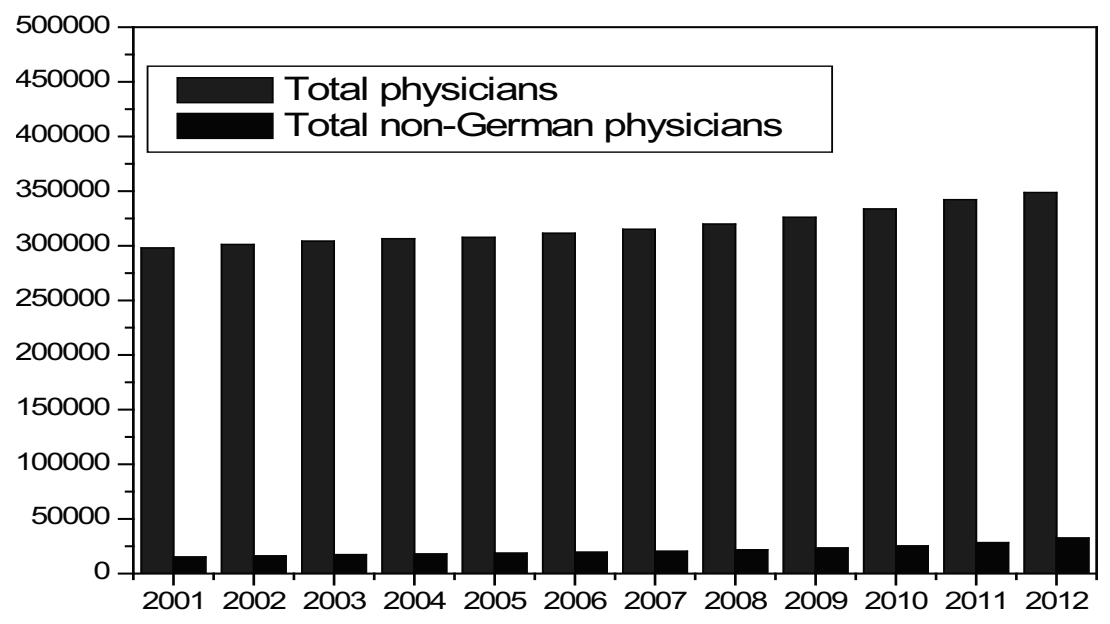

Figure 2 Evolution of the number of physicians in Germany

Hence, it is too early to assess whether the requirement to pass the state of knowledge exam could become a new barrier for the labour market integration of non-EU doctors in Germany. However, interviews suggest that such a possibility cannot be excluded because education and specialty training of non-EU doctors are usually considered incomplete by the institutions in charge of evaluating credentials. As a member of a German Integration for Qualification Network noted regarding the case of non-EU applicants, "Deficits are almost always identified, so that to compensate for such deficits, it is necessary to pass a state of knowledge exam, which is comparable to the German state exam and concerns the subjects Medicine, Surgery and a subject of free choice" (Integration durch Qualifikation Netzwerk, personal communication, Eastern Germany, April 16, 2013). With respect to specialty training, a member of a State Chamber noted that training carried out in non-EU countries is usually one or two years shorter than the training period expected by German authorities, which always implies that the applicant is required to do complementary training or to pass the specialty exam (Physicians Chamber, personal communication, Northern Germany, April 19, 2013).

While the specialty recognition of EU-citizens from old EU countries is based on a "38-year-long recognition practice", there seems to be concern about automatic recognition of specialty degrees obtained in new EU 
Member States: "Despite the formally recognised equivalence of medical training in the European Union, the content of medical training in EU Member States is still not known in full, nor compared or coordinated. Equivalence with respect to duration and content cannot always be investigated or guessed" (Physicians Chamber, personal communication, Northern Germany, April 19, 2013). Finally, information suggests that some administrations are more restrictive than others in regard to assessing applicants' foreign credentials. The vice-director of the human resources department of a large hospital in Northern Germany, for instance, seemed very concerned about the attitude of the public office responsible for credential recognition,

They say that they are overworked, but our feeling is that arbitrariness also plays a role ... and ... and I do not think that they do not check carefully ... I think that they check more over-carefully ... But it is such a bureaucratic structure ... if they had a service attitude, then it would be easier for them and for us, too. They are often impossible to reach and only at limited times ... They do not respond to e-mails ... It takes about five days for a Berufserlaubnis to be sent by ordinary mail, and when we ask them to fax it, they say they don't do that ... (Human Resources Department, Hospital, personal communication, Northern Germany, April 18, 2013).

The hospital manager's statement contrasted with information provided by a representative of the office concerned, who responded that such differences had mainly to do with the staff available and that some Länder are more lax than others. In this respect, he noted that while his office assessed the authenticity of a document requiring certain forms of authentication, other Länder accepted a copy of the document. Such different practices are reflected in the numbers because the number of applicants increased more in some Länder than in others (State Health Ministry, Department responsible for degree recognition, Northern Germany, telephone interview, July, 15 , 2013). Apart from foreign credential recognition, other factors may challenge the labour market inclusion of foreign doctors. For instance, it remains to be seen to what extent the new rules will affect the number of self-employed foreign doctors with their own practice in Germany.

Taking over a practice not only represents a significant financial investment (even for German doctors) but also requires a certain degree of integration into informal medical networks. A recent study conducted on the professional expectations of young doctors in Germany indicates that more than half of the survey participants had already collected some prac- 
tice experience in the health sector before beginning their medical studies while almost 60 per cent had parents that were physicians themselves or had other physician relatives (Gibis et al., 2012). In view of this, the possibility for foreign doctors (including those coming from EU countries) to take over an attractive practice in an urban area is more limited in comparison to German citizens or foreigners who have conducted their medical studies in Germany and who already have an established network within the German health care sector.

For the time being, the only possibility to be a self-employed doctor is to take over a practice refused by German natives; these businesses are cheaper and far less attractive because they are often located in rural areas. This may also explain why in 2012, only 3,652 of 26,034 practicing foreign doctors were self-employed (niedergelassen) and more than half of them $(2,124)$ were European citizens (Bundesärztekammer, 2012). Finally, the language issue is now hotly debated by policy makers and scholars in Germany. Particularly in the case of doctors, the ambiguity of the language requirement has been perceived as an important contradiction in the current immigration approach. As an interviewee of the state recognition office noted, it is difficult to explain why it is necessary to have a proficiency level corresponding to $\mathrm{C}_{2}$ to study in Germany while it suffices to have $\mathrm{B}_{2}$ to work as a physician (State Health Ministry, Department responsible for degree recognition, Northern Germany, telephone interview, July $15,2013)$. In addition, experts observe that many $\mathrm{B}_{2}$ certificates are often only graded 'sufficient', meaning that foreign doctors do not possess good language abilities despite passing the required language exam,

There is the requirement to pass the $\mathrm{B}_{2}$ examination, preferably at the GoetheInstitute ... I think that, despite what they ask ... I think that most of them really learn to understand and talk, and have the courage to talk, here ... With some people, you think, "Have they understood me? Have they not understood me? Then you find out that they understood something completely differently, but did not want to talk about it ... I was often under the impression that we use figures of speech they do not know. If somebody comes to Germany, he or she has a lot to face (Human Resources Department, Hospital, Northern Germany, personal communication, April 18, 2013).

As a consequence of the increasing debate on this issue, several State Chambers have initiated programmes to improve German language skills. The individual state ministries of health have also agreed on introducing a common evaluation mechanism to check the language proficiency of full 
licence applicants. However, talk about increasing language requirements is characterised by widespread inertia that, so far, contrasts with the growing concern for the problem (Laubenthal, 2012). According to a civil servant of the Federal Office for Immigration and Refugees, postponement of increasing language requirements relates to the fear that increased requirements could affect Germany's attractiveness to foreign physicians (Bundesamt für Migration und Flüchtlinge, telephone interview, September 17, 2013). Similarly, another state government official observed that the language issue may cut two ways because no one will come to Germany if the prerequisites are too high (State health ministry, Department responsible for degree recognition, Northern Germany, telephone interview, July 15, 2013). In any case, the slowness of German authorities in tackling this problem is striking considering the relevance of the language factor in the overall integration debate in Germany and Europe.

\section{$7 \quad$ Discussion and Conclusion}

This article analysed how recruitment of highly skilled foreign workers can be managed in a traditionally exclusive field such as the medical profession, using Germany and Spain as comparative examples. As was seen, both countries allow the entry of non-EU physicians. This notwithstanding, the analysis showed that structural factors play a major role in determining to what extent a more open immigration process occurs.

The centralized organisation of the Spanish training system, together with the weak corporatism of the medical profession, allowed for quick reaction to the entry of highly skilled migrants as the cap for specialty training access was lifted during the economic boom. The same centralized organisation was also fundamental when it came to restrict, though not forbid, medical training for non-EU foreigners after the economic crisis. In this respect, the Spanish case reflects the expected relationship between international recruitment and strong economic fluctuations usually assumed in the case of tax-based systems (Hoesch, 2012). The German case, by contrast, experienced an unexpected evolution. Social-insurance-based systems such as Germany's, where individual financial turnover plays a major role, are generally considered less favourable in promoting international recruitment. However, the strong corporatist character could not prevent the exceptional opening of the immigration policy that Germany experienced after years of closure, which also affected the health care sector. 
Analysis has also shown that health care systems always keep control of their workers despite more flexible recruitment channels. Before the economic crisis, specialty recognition represented a difficult obstacle for those who had carried out their medical training abroad and wanted it recognised in Spain. Moreover, employment in the public health care sector has always been "reserved" for Spanish natives and non-EU citizens, similar to many other positions in the public administration. This outcome suggests that the medical profession in Spain is still linked to the idea of "national service" and "national interest", which is, at least for now, not the case in Germany anymore. However, German licensing bodies still keep considerable power in the process of foreign credential recognition. The different recognition practices implemented in the German Länder, after lifting the nationality requirements, may turn foreign credential recognition into an important recruitment barrier to labour market integration. The requirement to pass a state of knowledge exam in the case of assessed education gaps may considerably delay the recruitment process and challenge an efficient match of demand and supply. In addition to the use of nationality requirements and credential recognition as ex ante and ex post control instruments, respectively, the impact of less debated factors, such as language, on the employment of foreign physicians has been taken into account. It has been shown that scant knowledge of German is considered one of the reasons for the difficult labour market integration of foreign doctors and is currently one of the most debated challenges to Germany's attractiveness to highly skilled foreign workers. By contrast, language in Spain has never represented an obstacle to full access to the medical profession due to the high presence of Latin Americans among resident physicians.

Clearly, the internationalisation of the Spanish and German health care sectors, although in different stages, experienced a reverse trend in which national citizenship and foreign credential recognition represent the main instruments to "ration" the access of non-EU foreigners. Another less evident limitation of these recruitment regimes concerns the type of workers to be recruited. As was seen, in both countries, the demand for foreign physicians is limited to certain geographic regions of destination and certain specialties. Family medicine represents by far the least attractive medical specialty in both countries because it is less prestigious and has fewer opportunities for additional income compared to other specialties. In Germany, family doctors receive the lowest premiums from German insurance, whereas in Spain, they earn less than other types of specialists and have fewer possibilities to open their own private practice. In other words, 
the demand for physicians in both countries exists in the less attractive positions, which also influences the types of positions offered. As was seen, Spanish international recruitment schemes are mainly focused on specialty training while Spanish and EU nationals have always had priority in obtaining the "good" permanent positions in the public system both before and after the economic crisis. In this respect, Spanish recruitment reform was not an avenue to attract human capital for long-term employment but was rather an avenue to bring the least expensive category of physicians into the country. It is also legitimate to question to what extent the current reforms in Germany will contribute to human capital enhancement or simply "fill in the blanks" of unattractive positions since the reduction of the minimum salary requirement mainly favours the recruitment of young non-specialised doctors rather than that of more experienced (and expensive) specialised doctors. ${ }^{6}$

This result suggests that Germany is following a pattern similar to Spain, where the opening of the health care sector to non-EU foreigners mainly concerns medical training. Second, the emergence of internal barriers based on foreign credential recognition may put the German case closer to Canada, where effective integration into the labour market is difficult despite the existence of more generous entry rules. It also remains to be seen to what extent foreign doctors will be able to open their own practice as self-employed specialists, considering the relevance that private networks have in the process of "practice-takeover", which represents the more profitable business in the German health sector (Hoesch, 2012). In view of all this, it could eventually be argued that the recruitment policies in these countries are not aimed at attracting valuable human capital but rather at responding to the "segmented" structure of the respective health care systems where immigrants, most of them from third countries, have to fill the less attractive niches while the most attractive positions remain concentrated in the hands of natives and privileged nationals.

\section{Notes}

1. Academic recognition refers to the university degree obtained after the study of medicine while the recognition of professional qualification refers to specialty training carried out after having obtained a degree in medicine. In Germany and Spain, physicians are allowed to practice as specialists only after having concluded their specialty training.

2. According to the current wage agreements, the minimum gross salary for resident doctors to earn in their first year of training is of 4,023 euros monthly. 
3. In fact, candidates with a poor ranking position in the state examination repeated the training exam, hoping to achieve a better score instead of starting medical training in less attractive specialties, such as FCM.

4. The immigration reform of 2004 in Spain introduced the possibility of circumventing labour market checks for occupations included in the "Catalogue of Hard-to-Fill Occupations" (Catalogo de ocupaciones de dificil cobertura). According to this new procedure, if a vacancy refers to a type of job listed in the Catalogue, an employer can immediately initiate the hiring process without the need for a labour market check. For further details, see Finotelli (2012).

5. See $\S 3$ of the current Regulation of the Medical Profession.

6. It may also be argued that such a low minimum salary may favour international recruitment in Eastern German regions, where doctors in hospitals are supposed to earn less than in the Western part of Germany; opening a practice in Eastern Germany is less lucrative because of a lower number of private patients.

\section{References}

Amaya Pombo, C. \& García Perez, M. (2005). Demografía medica en España. Mirando al futuro [Medical Demography in Spain: Looking at the Future], Madrid: CESM.

Blum, K. \& Löffert, S. (2010). Ärztemangel im Krankenhaus: Ausmaß, Ursachen, Gegenmaßnahmen [The Demand of Physicians in Hospitals: Dimensions, Causes and Countermeasures]. Düsseldorf, Deutsches Krankenhaus Institut. Available online at: https:/www.dki.de/sites/ default/files/publikationen/langfassung_aerztemangelı.pdf

Bommes, M., Hoesch, K., Kolb, H.\& Hunger, U. (eds.) (2004). Organisational Recruitment and Patterns of Migration. Interdependencies in an Integrating Europe. Osnabrück, Institut für Migrationsforschung und Interkulturelle Studien (IMIS-Beiträge 25).

Boyd, M. \& Schellenberg, G. (2007). Re-accreditation and occupations of immigrant doctors and engineers. In: Canadian Social Trends, 84, pp. 2-10. Available online at: http://www.statcan.gc.ca/pub/11-008-x/2007004/pdf/10312-eng.pdf

Buchan, J. (2006). Migration of health workers in Europe: policy problem or policy solution? In: Dubois, C, McKee M, Nolte E (eds.), Human resources for Health in Europe. Berkshire: Open University Press.

Bundesärztekammer (BAEK), (2011a). Written document on the new recognition law, 14 March 2011 (available upon request to the author).

Bundesärztekammer (BAEK), (2011b). Written document on the new recognition law, 17 June 2011 (available upon request to the author).

Bundesärztekammer (BAEK), 2012. Ausländische Ärzte und Ärztinnen [Foreign doctors]. Available online at: http://www.bundesaerztekammer.de/page.asp?his=0.3.1667.11372.11382

De Miguel, J.A. (1982). Para un análisis sociológico de la profesión medica [Towards a Sociological Análisis of the Medical Profession], Revista de Investigaciones Sociológicas, 20, pp. 101-120.

Den Adel, M., Blau, W., Dobson, J., Hoesh, K. \& Salt, J. (2004). Recruitment and the migration of foreign workers in health and social care. In: Bommes, M., Hoesch, K., Hunger, U. \& Kolb, H. (eds.), Organisational Recruitment and Patterns of Migration. Interdependencies in an Integrating Europe, Imis Beiträge 25, pp. 201-30.

Dixon, M. (2013). Skills, Professional Regulation, and international mobility in the engineering workforce. Washington: Migration Policy Institute. Available online at: http://www.migra- 
tionpolicy.org/research/skills-professional-regulation-and-international-mobility-engineering-workforce.

Docquier, F. \& Bhargava, A. (2006). Medical brain drain - A New Panel Data Set on Physicians Emigration Rates (1991-2004). Washington DC: World Bank.

Döhler, M. \& Manow, P. (1995). Staatliche Reformpolitik und die Rolle der Verbände im Gesundheitssektor [State Reform Policy and the Role of Associations in the Health Care Sector]. In: Mayntz, R. \& Scharpf, F.W. (eds.Gesellschaftliche Selbstregelung und politische Steuerung [Society Auto-Regulation and Policy Making]. Frankfurt/New York, Lang, pp. 140-168.

Dussault G., Buchan, J., Sermeus, W. \& Padaiga, Z. (2010). Assessing future health workforce needs. Copenhagen, WHO.

Englmann, B. \& Müller, M. (2007). Die Anerkennung von ausländischen Qualifikationen in Deutschland [The Recognition of Foreign Qualifications in Germany]. Available online at: www.berufliche-anerkennung.de/brain-waste.html

Espeler, U. (2000). Zur Erteilung der Approbation an ausländische Ärzte [The Issue of the Licence to Practice to Foreign Doctors]. MedR, 7, pp. 333-335.

European Commission, (2007). Press release IP/o7/1575, 23/10/2007. Available online at: http:// europa.eu/rapid/pressReleasesAction.do?reference=IP/07/1575

European Commission, (2008). Green Paper on the European Workforce for Health, COM(2008) 725 final. Available online at: http://ec.europa.eu/health/ph_systems/docs/workforce_gp_en.pdf

Finotelli, C. (2012). Spain: Case study report. Working Paper for the Project 'Labour Migration Governance in Contemporary Europe'. Available online at: www.labmiggov.eu.

Finotelli, C. (2014). The international recruitment of physicians and IT and engineering specialists in Germany and Spain: actors, processes and challenges. Available online at: www.labmiggov.eu

Forcier, M. B., Simoens, S. \& Giuffrida, A. (2004). Impact, regulation and health policy implications of physician migration in OECD countries, Human Resources for Health, 2(12), http:// www.human-resources-health.com/content/2/1/12

Freidson, E. (1970). The Profession of Medicine. A Study of the Sociology of Applied Knowledge. Chicago: University of Chicago Press.

Gibis, B., Heinz, A., Jacob, R. \& Müller, C.H. (2012). Berufserwartungen von Medizinstudierenden: Ergebnisse einer bundesweiten Befragung [Labour Expectations of Medicine Students: Results of a Federal Survey], Deutsches Ärzteblatt, 109 (18), pp. 327-32.

Glinos, Irene A. (2014). Going beyond numbers: A typology of health professional mobility inside and outside the European Union, Policy and Society, 33(1), pp. 25-37.

González López-Valcárcel B., Pérez Barber, P. \& Rubio Ortun, V. (2011). ¿Por qué los médicos huyen y rehúyen la Medicina de Familia? Datos y claves sobre el problema en busca de soluciones [Why do Doctors run Hawai from Family Medecine? Data, key issues and search for a solution on the problem]. In: Ortún V. (ed). La refundación de la Atención Primaria [Refounding Primary Care]. Madrid: Springer, pp. 37-51.

Grignon, M., Owusu Y. \& Sweetman, A. (2012). The International Migration of Health Professionals. In: Constant, A.F. \&Zimmermann, K.F. (eds.), The International Handbook on the Economics of Migration. Cheltenham: Edward Elgar, pp. 75-97.

Harris, J., González López-Valcárcel, B., Ortún, V. \& Barber, B. (2013). Specialty choice in times of economic crisis: a cross-sectional survey of Spanish medical students, British Medical Journal, 3(2), 2013;3:e002051.doi:10.1136/bmjopen-2012-002051.

Hoesch, K. (2009). Was bewegt Mediziner? Die Migration von Ärzten und Pflegepersonal in Deutschland und Grossbritannien [What moves health professionals? The migration of doctors and care workers in Germany and the UK]. Münster: LIT.

Hoesch, K. (2012). Migrant Britain, sustainable Germany: Explaining differences in the interna- 
tional migration of health professionals, Oxford, Compas, Working Paper n. 12-99. Available online at: http://www.compas.ox.ac.uk/publications/working-papers/wp-12-99/

Iredale, R. (2001). The Migration of Professionals: Theories and Typologies, International Migration, 39(5), pp. 7-26.

Jinks, C., Ong, C.N. \& Paton, B. (2000). Mobile medics? The mobility of doctors in the European Economic Area, Health policy, 54(1), pp. 45-64.

Kale, E. \& Raza Syed, H. (2010). Language barriers and the use of interpreters in the public health services. A questionnaire-based survey, Patient Education and Counceling, 81(2), pp. 187-191.

Kolb, H. (2014). When Extremes Converge - German and Canadian Labor Migration Policy Compared, Comparative Migration Studies, 2(1), pp. 57-7.

Kolb, H., Murteira, S., Peixoto, J., \& Sabino, C. (2004). Recruitment and Migration in the ICT Sector. In: Bommes, M., Hoesch, K., Hunger, U. \& Kolb, H. (eds.). Organisational Recruitment and Patterns of Migration. Interdependencies in an Integrating Europe, Imis Beiträge 25, pp. 147-177.

Kopesch, T. (2010). Dem deutschen Gesundheitswesen gehen die Ärzte aus! Studie zur Altersstruktur und Arztzahlentwicklung, Berlin [The German Health Care Sector is loosing Physicians! A Study on Physicians' Age Structure and Figures]. Available online at: http:// www.bundesaerztekammer.de/page.asp?his=0.3.1667.1697.1706

Laubenthal, B. (2012). Germany: Case study report. Working Paper for the Project 'Labour Migration Governance in Contemporary Europe'. Available at: www.labmiggov.eu

Lavenex, S. (2006). The Competition State and the Multilateral Liberalization of High Skilled Migration. In: Smith, M.P. and Favell, A. (eds.). The Human Face of Global Mobility. International Highly Skilled Migration in Europe, North America and the Asia-Pacific. New Brunswick, Transaction, pp. 29-52.

McGrath, B. (2004). Integration of overseas-trained doctors into the Australian medical workforce, $M J A, 181(11 / 12)$, pp. 640-642.

OECD (2013). Recruiting Immigrant Workers: Germany. Paris: OECD.

OECD (2011). OECD Health Statistics. Paris: OECD.

Paris, V., Devaux \& M., Wei, L. (2010). Health Systems Institutional Characteristics. A Survey of 29 OECD Countries. Paris: OECD (OECD Health Working Papers, 50).

Peixoto, J. (2001). Migration and Policies in the European Union: Highly Skilled Mobility, Free Movement of Labour and Recognition of Diplomas, International Migration, 39( $(7)$, pp. 33-61.

Ramirez, J.P. (2013). Sanidad rechaza el 80\% de los expedientes de homologación de médicos extracomunitarios [The Health Ministry rejects 80 per cent of the Recognition Applications of non-EU Physicians], Gaceta medica, 24 May 2013.

Ribeiro, J. S. (2008a). Migration and Occupational Integration: Foreign Health Professionals in Portugal. In Saks, M. \& Kuhlmann, E. (eds.), Rethinking professional governance: International Directions in Health Care, Bristol, The Policy Press, pp. 201-215.

Ribeiro, J. S. (2008b). Gendering migration flows: physicians and nurses in Portugal, Equal Opportunities International, $27(1)$, pp. 77-87.

Rodriguez, J. (1981). El poder medico desde la sociología [Medical Power from a Sociological Perspective], Revista Española de Investigaciones Sociológicas, 14, pp. 95-112.

Schiller, M. (2010). Der Berufszugang ausländischer Ärzte. Eine systematisierende Darstellung der Approbationsvoraussetzungen in Fällen mit Auslandsbezug unter Berücksichtigung der aktuellen Rechtsprechung [Foreign Physicians' Access to the Labour Market. A Systematic Representation of Licencing Opportunities for Foreigners according to the current Jurisdiction], $M e d R, 28$, pp. 79-86.

Sumpton, M. (2013). Tackling the Brain Waste. Strategies to Improve the Immigrants' Foreign 
Qualification. Available online at: http://migrationpolicy.org/research/tackling-brain-wastestrategies-improve-recognition-immigrants $\% \mathrm{E} 2 \% 80 \% 99$-foreign-qualifications

Tousjin, W. (2009). I medici in Italia: motivazioni, autonomia, appartenenza [Physicians in Italy: Motivations, Autonomy, Belonging]. Bologna, Il Mulino.

Wismar, M., Maier, C., Glinos, I., Dussault, G. \& Figueras, J. (2011). Health Professional Mobility and Health Systems. Evidence from 17 European countries. Kopenhagen: WHO.

Yamamura, S. (2009). „Brain Waste” ausländischer Ärztinnen und Ärzte in Deutschland, Wirtschaftsdienst, 3, pp. 196-201.

\section{About the Author}

Claudia Finotelli (Dr. Phil., University of Münster) is Senior Research Fellow (Ramón y Cajal Programme) at the Universidad Complutense de Madrid and Research Associate at the Instituto Universitario OrtegaMarañón in Madrid.

Email: cfinotel@cps.ucm.es 